\title{
Treatment of low strength sewage with high suspended organic matter content in an anaerobic sequencing batch reactor and modeling application
}

\author{
Andrés Donoso-Bravo* \\ Escuela de Ingeniería Bioquímica \\ Pontificia Universidad Católica de Valparaíso \\ Tel: 56322273819 \\ Fax: 56322273803 \\ E-mail: andres.donoso.b@mail.ucv.cl \\ Marta Carballa \\ Escuela de Ingeniería Bioquímica \\ Pontificia Universidad Católica de Valparaíso \\ Valparaíso, Chile \\ Gonzalo Ruiz- Filippi \\ Escuela de Ingeniería Bioquímica \\ Pontificia Universidad Católica de Valparaíso \\ Valparaíso, Chile \\ Rolando Chamy \\ Escuela de Ingeniería Bioquímica \\ Pontificia Universidad Católica de Valparaíso \\ Valparaíso, Chile
}

Financial support: FONDECYT project (n¹080329).

Keywords: acidogenesis, anaerobic treatment, hydrolysis, low strength wastewater, modeling.

Abbreviations: $\alpha$ : particulate organic matter fraction

ASBR: anaerobic sequencing batch reactor

CSTR: continuous stirred tank reactor

COD: chemical oxygen demand

IA: intermediate alkalinity

OLR: organic load rate

PA: partial alkalinity

pCOD: particulate COD

sCOD: soluble COD

TA: total alkalinity

tCOD: total COD

TSS: total suspended solids

UASB: up-flow anaerobic sludge blanket

VFA: volatile fatty acid

VSS: volatile suspended solids

In this work, an anaerobic sequencing batch reactor (ASBR) was operated for 8 months to treat low strength sewage with high suspended organic matter content. Three phases of operation with increasing organic loading rates (OLR) were performed: $0.4 \mathrm{~kg} \mathrm{COD} / \mathrm{m}^{3} \mathrm{x}$ $\mathrm{d}$ (phase I), $0.8 \mathrm{~kg} \mathrm{COD} / \mathrm{m}^{3} \times \mathrm{d}$ (phase II) and $1.2 \mathrm{~kg}$ $\mathrm{COD} / \mathrm{m}^{3} \times \mathrm{d}$ (phase III). Adequate stability parameters (pH, total alkalinity) were obtained through all three experimental phases. During phases I and II, the removal efficiencies of organic matter (expressed as total chemical oxygen demand (COD) and total suspended solids ranged between $50-60 \%$. However, these values decreased to $15-25 \%$ in phase III. In addition, a non-complex model, including hydrolysis, acidogenesis and methanogenesis, was applied to predict the reactor behavior.

\footnotetext{
*Corresponding author
} 


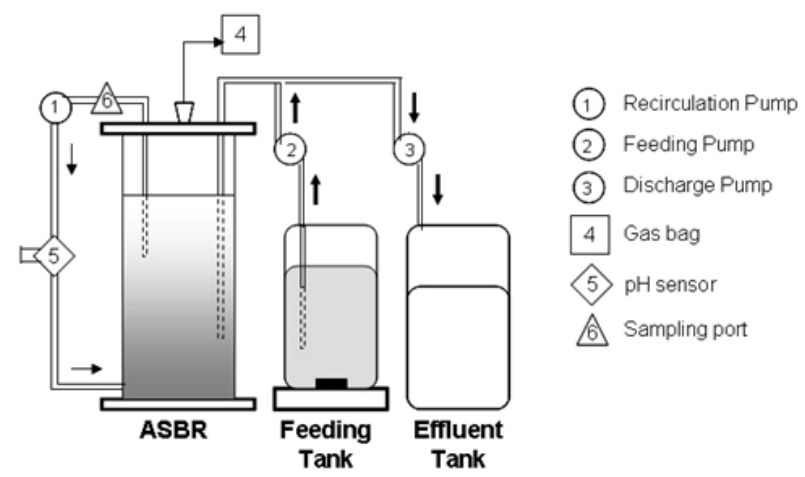

Figure 1. Scheme of the experimental system implemented for the anaerobic treatment of low strength sewage with high suspended organic matter content.

Anaerobic digestion processes have been mainly applied to high strength wastes and wastewaters, such as winery effluents, brewery slurries or sludge from wastewater treatment plants. Low strength wastewaters, like sewage, have not been extensively treated in anaerobic systems, although some reactors are operating in tropical countries.

Anaerobic reactors are an attractive alternative for sewage treatment in small communities not only due to low investment and operational costs, but also due to the low amounts of sludge produced and the energy recovered (i.e. biogas production).

The anaerobic treatment of these effluent types using continuous reactors (continuous stirred tank reactor (CSTR), upflow anaerobic sludge bed (UASB), etc) presents two main disadvantages. First, the organic matter concentrations are in the same range or only slightly higher than the affinity constant values for anaerobic biomass $\left(\mathrm{K}_{\mathrm{s}}\right)$, and therefore the microorganisms do not work at high specific growth rates according to the Monod equation. Second, if a high fraction of particulate or suspended organic matter is present, the overall reaction slows down even further since hydrolysis of the complex particulates must occur first, which can become the limiting step of the whole process.

Anaerobic sequencing batch reactors (ASBR), developed by Sung and Dague (1995), are anaerobic systems which work in five-stage cycles: feeding, reaction, settling, discharge and idle time. These reactors have several advantages compared to continuous systems. At the beginning of the reaction stage, the organic matter concentration is at its maximum level, which in turn maximizes the degradation rate since the substrate concentration is greater than the affinity constant. In addition, several feeding strategies can be applied allowing batch, fed-batch or a combination of both (Zaiat et al. 2001), and the reaction and settling steps occur in the same tank. ASBRs have been mainly applied for the treatment of high strength wastes (Ruiz et al. 2002; Massé et al. 2003; Mockaitis et al. 2006; Ndegwa et al. 2008), although some studies with low strength wastewaters have also been performed (Bodik et al. 2002). The main drawback would be that the batch operation is not feasible for continuously discharged effluents. However, this situation might be overcome by using ASBRs in parallel.

The benefits of the implementation of mathematical models in wastewater treatment systems have been described by

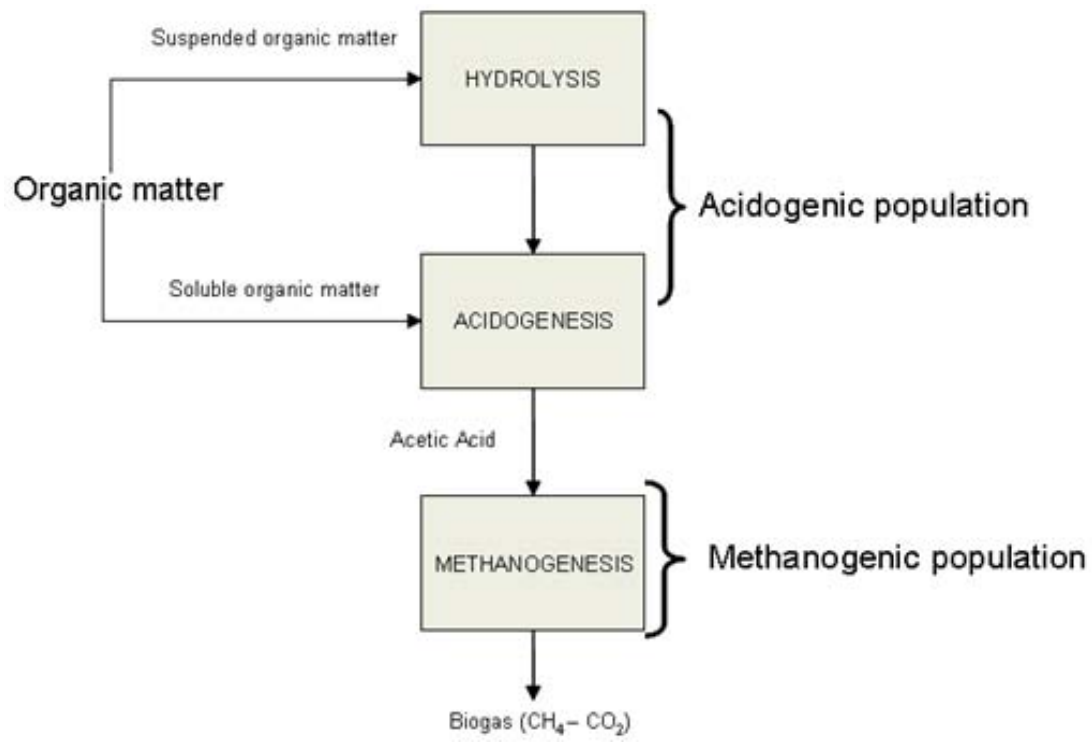

Figure 2. Simplified anaerobic digestion process used in the model. 

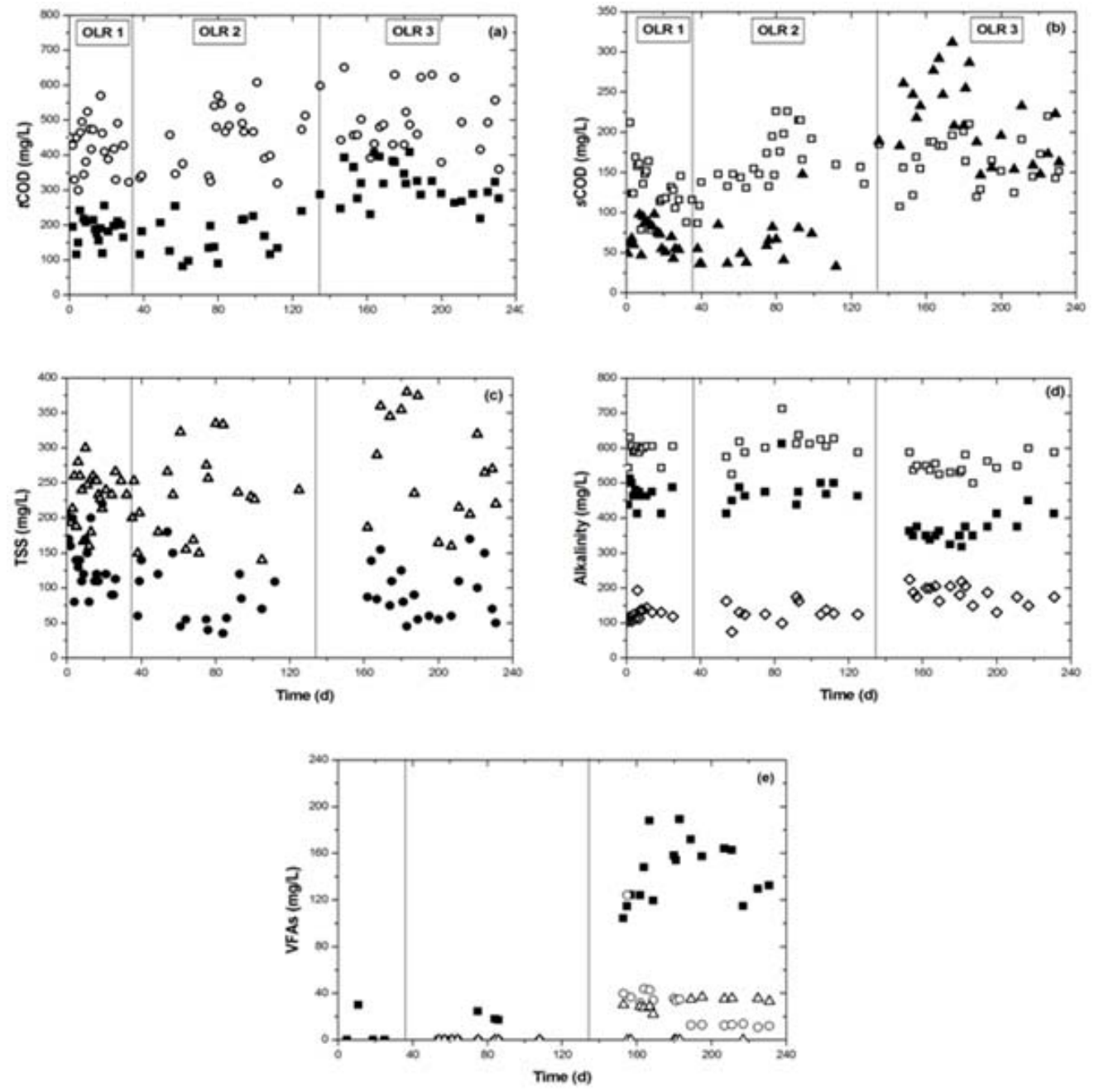

Figure 3. ASBR performance treating low strength sewage with high suspended organic matter content. a) $t C O D$ : (o) influent and ( $\bullet$ ) effluent; b) sCOD: ( $\square$ ) influent and $(\boldsymbol{\Delta})$ effluent; c) TSS: $(\Delta)$ influent and $(\bullet)$ effluent; d) Alkalinity: $(\square)$ TA, $(\bullet)$ partial alkalinity (PA) and $(\diamond)$ IA; e) VFAs: ( $\bullet$ Acetic acid, $(\Delta)$ Propionic acid and $(\circ)$ Butyric acid of the effluent.

many authors (Dochain and Vanrolleghem, 2001; Batstone et al. 2002). Different models have been applied in ASBRs, which were mainly validated with readily biodegradable and high-strength substrates. Most of them required many kinetic parameters and large systems of differential equations, and were therefore difficult to use for control purposes (Bagley and Brodkorb, 1999; Massé and Droste, 2000). Bernard et al. (2001) developed a simplified model using only two populations, acidogenic and methanogenic, which considerably reduced the number of kinetic parameters. Moreover, a great number of studies have been performed to determine the kinetic parameters of the acidogenic and methanogenic populations using different substrates, such as lactose, glucose, oils, solid vegetable wastes and volatile fatty acids (VFAs) (Bernard et al. 2001; Batstone et al. 2002). The values obtained for the different parameters varied among the different studies, due to the different specific experimental conditions used in each case.
The aim of this study was to evaluate the performance of an ASBR for the treatment of very low strength synthetic wastewater with high suspended organic matter content. Additionally, a simplified model with reported kinetic parameters was evaluated to predict the system behavior.

\section{MATERIALS AND METHODS}

\section{Experimental set-up}

A double-jacked reactor with a $4.0 \mathrm{~L}$ effective volume was used. It was operated at $35^{\circ} \mathrm{C}$, using a thermostatically regulated water bath, with $1 \mathrm{~h}$-cycles consisting of $20 \mathrm{~min}$ of feeding, $30 \mathrm{~min}$ of settling, $45 \mathrm{~min}$ of discharge and 10 min of idle time. The reaction times varied according to the organic load rate (OLR) applied, i.e. $1335 \mathrm{~min}, 615 \mathrm{~min}$ and 375 min, respectively. The reactor was mixed during the reaction stage by mixed-liquor recirculation in order to improve the mass transfer between the biomass and 

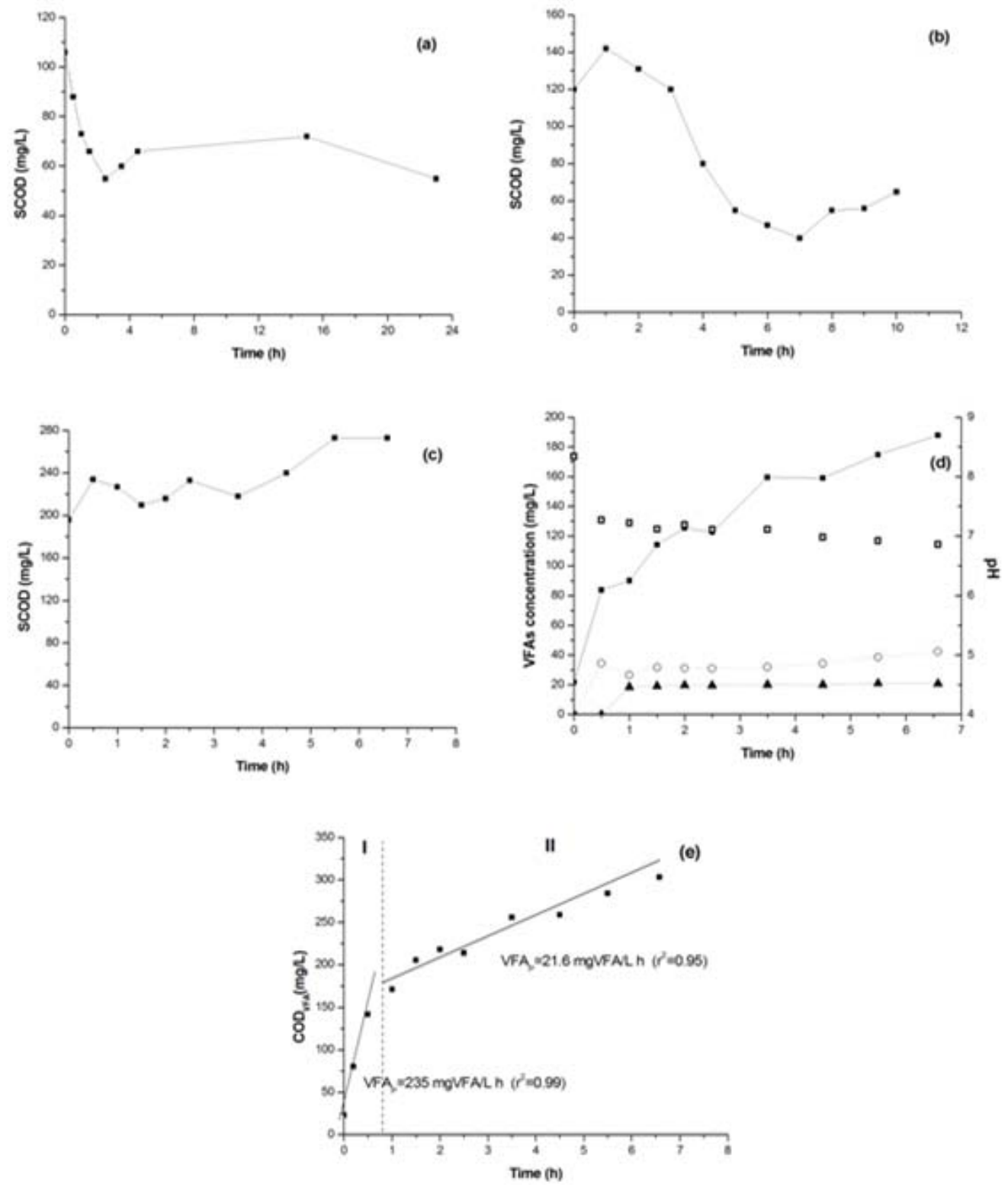

Figure 4. sCOD concentrations during the reaction stage of: (a) phase I; (b) phase II; (c) phase III; (d) VFA concentration variation:

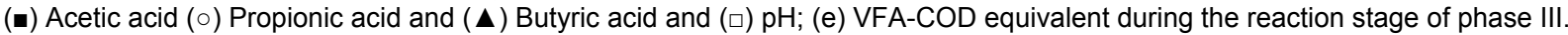

substrate. Peristaltic pumps were used for feeding, effluent discharge and mixed liquor recirculation.

Due to the low strength of the synthetic wastewaters used in this study, unreliable results of biogas production were obtained (data not shown). This was also reported previously (Ruiz et al. 2001; Rodrigues et al. 2003) even using more concentrated wastewaters ( $5 \mathrm{~g} \mathrm{COD/L)}$. In these studies, the biogas production was estimated either with an empirical model or from off-line measurements of COD, volatile fatty acids (VFA) or suspended solids.

The system operated for 8 months and three phases were performed with increasing OLR: $0.4 \mathrm{~kg} C O D / \mathrm{m}^{3} \mathrm{x} \mathrm{d}(1$ cycle/d), $0.8 \mathrm{~kg} \mathrm{COD} / \mathrm{m}^{3} \mathrm{x} \mathrm{d}$ (2 cycles $\left./ \mathrm{d}\right)$ and $1.2 \mathrm{~kg}$ $\mathrm{COD} / \mathrm{m}^{3} \mathrm{x}$ d (3 cycles/d). Each OLR was maintained until the pseudo-steady state (constant removal efficiencies) was achieved. The automated operation of the system (pumps, valves and mixer) was programmed in Microwin STEP7 using a PLC Siemmens ${ }^{\circledR}$ S7200. Figure 1 shows a diagram of the implemented system.

\section{Wastewater and inoculum}

The reactor feed was prepared synthetically and its composition was as follows: potato solution $4.0 \mathrm{~g} / \mathrm{L}$, ovoalbumin $0.12 \mathrm{~g} / \mathrm{L}$, vegetable oil $0.025 \mathrm{~g} / \mathrm{L}$ and urea $0.033 \mathrm{~g} / \mathrm{L}$. In addition, both macro $\left(\mathrm{NH}_{4} \mathrm{Cl} 0.074 \mathrm{~g} / \mathrm{L}\right.$ and 

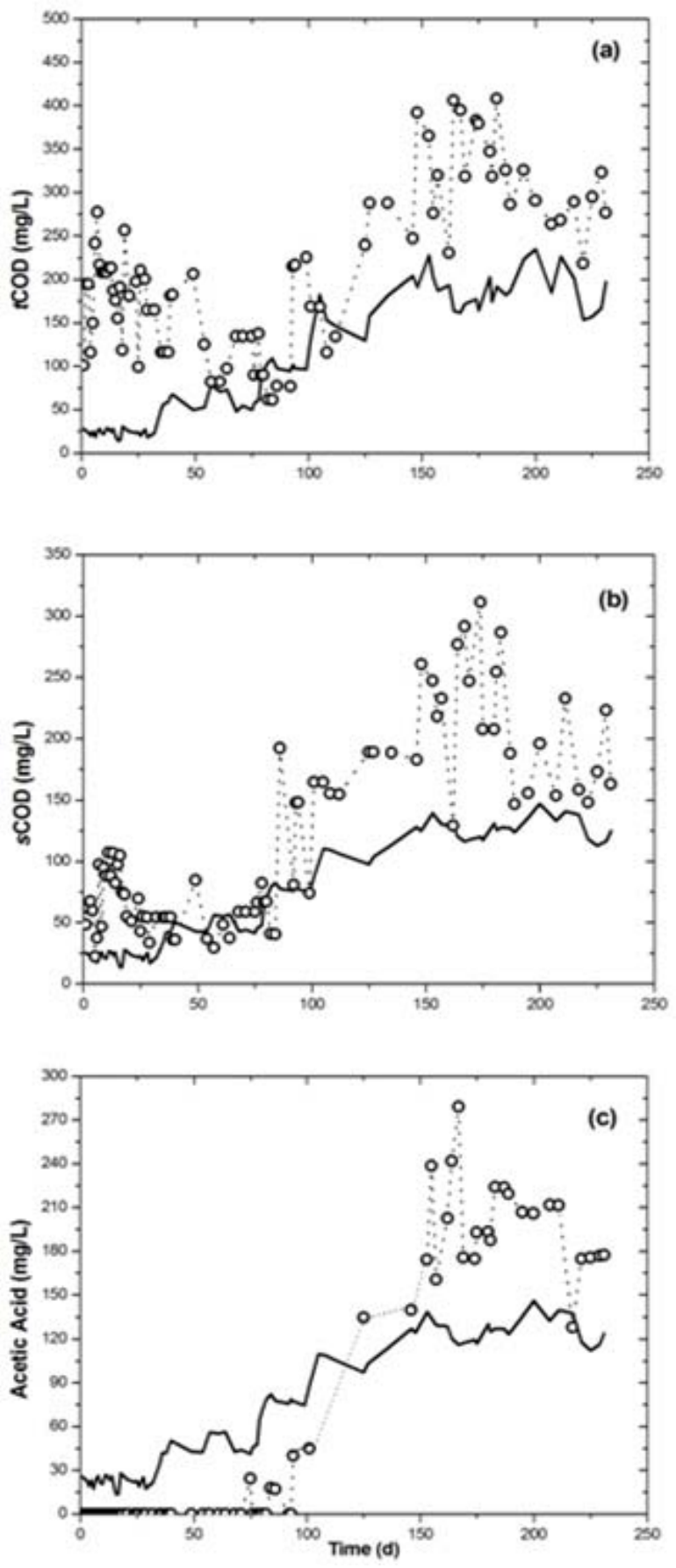

Figure 5. Comparison between modeled data (-) and experimental data ( $($ ). Total (a) and soluble (b) COD and acetic acid (c) concentrations.

$\left.\mathrm{KH}_{2} \mathrm{PO}_{4} 0.01 \mathrm{~g} / \mathrm{L}\right)$ and micronutrients $\left(\mathrm{FeCl}_{3} \cdot 4 \mathrm{H}_{2} \mathrm{O} 0.004\right.$ $\mathrm{g} / \mathrm{L}, \quad \mathrm{ZnCl}_{2} 1 \mathrm{x} \quad 10^{-4} \mathrm{~g} / \mathrm{L}, \quad \mathrm{MnCl}_{2} \cdot 4 \mathrm{H}_{2} \mathrm{O} \quad 0.001 \mathrm{~g} / \mathrm{L}$, $\mathrm{CoCl}_{2} \cdot 6 \mathrm{H}_{2} \mathrm{O} 0.004 \mathrm{~g} / \mathrm{L}, \mathrm{CuCl}_{2} \cdot 2 \mathrm{H}_{2} \mathrm{O} 6 \cdot 10^{-5} \mathrm{~g} / \mathrm{L}, \mathrm{NiCl}_{2} \cdot 6 \mathrm{H}_{2} \mathrm{O}$ $1 \times 10^{-4} \mathrm{~g} / \mathrm{L}, \mathrm{H}_{3} \mathrm{BO}_{3} 1 \times 10^{-4} \mathrm{~g} / \mathrm{L}, \mathrm{Na}_{2} \mathrm{SeO}_{3} \cdot 2 \mathrm{H}_{2} \mathrm{O} 2 \times 10^{-4}$ $\mathrm{g} / \mathrm{L}$ and $\left(\mathrm{NH}_{4}\right) 6 \mathrm{MoO}_{2} \cdot 4 \mathrm{H}_{2} \mathrm{O} 1.8 \times 10^{-4} \mathrm{~g} / \mathrm{L}$ ) were included in the formulation. To maintain alkalinity, $0.5 \mathrm{~g} / \mathrm{L} \mathrm{NaHCO}_{3}$ was also added.
The reactor was seeded with sludge from a lab-scale UASB reactor treating synthetic ethanol wastewater, whose methanogenic activity was $0.62 \mathrm{~g} \mathrm{COD}_{\mathrm{CH}} / \mathrm{gVSS} \times \mathrm{d}$. The final concentration of biomass in the reactor was $5 \mathrm{~g}$ VSS/L.

\section{Analytical methods}

The $\mathrm{pH}$, total (tCOD) and soluble (sCOD) COD, total suspended solids (TSS) and volatile suspended solids (VSS) and total alkalinity (TA) and intermediate alkalinity (IA) were determined according to standard methods (APHA, 1995). Samples for sCOD and VFAs were filtered through glass-fiber filters prior to testing (Whatman GF/C). VFAs were determined by gas chromatography. Methane production was measured by liquid displacement $(\mathrm{NaOH}$ solution). The methanogenic activity test was performed in $100 \mathrm{~mL}$ serum bottles with a $1.5 \mathrm{~g}$ VSS/L biomass concentration, using the method developed by Soto et al. (1993)

\section{Mathematical model}

The model evaluated included three phases (hydrolysis, acidogenesis and methanogenesis), was based on the model developed by Bernard et al. (2001) (Figure 2) and has already been used in previous studies for other substrates (Keshtkar et al. 2001).

To develop and implement the model, some assumptions were made: feeding, settling, discharge and idle times were not considered in the model, since the durations were assumed negligible compared to reaction time and the operational conditions did not facilitate the degradation of organic matter. The biomass concentration in the reactor at the beginning of each cycle is the same. At the end of each cycle, all non-degraded particulate matter settled to the bottom of the reactor and accumulated for the next cycle (i.e. $\mathrm{S}=1$ ).

A simple mass balance for a batch reactor is shown in equation 1.

$$
\frac{d \xi}{d t}=k_{i} \cdot r_{\xi}
$$

$\xi$ : state variable

$k_{i}$ : stoichiometric factor

$r_{\xi}:$ reaction rate

Despite more complex models that have been suggested (Vavilin et al. 2008), hydrolysis was considered as a first order kinetic reaction (equation 2), as recommended by most studies (Batstone et al. 2002). For acidogenesis and methanogenesis, a Monod-like model (equation 3) and a 
Haldane-like model including the inhibition by volatile fatty acids (equation 4) were considered, respectively.

$r_{0}=k_{0} \cdot X_{0} \cdot X_{1 \text { [Eq. 2] }}$

$r_{0}$ : rate of hydrolysis reaction $\left(\mathrm{d}^{-1}\right)$

$k_{0}$ : hydrolysis catalytic constant $\left(\mathrm{d}^{-1}\right)$

$X_{0}$ : suspended organic matter concentration (g/L)

$X_{1}$ : acidogenic biomass concentration $(\mathrm{g} / \mathrm{L})$

$r_{1}=\mu_{1} \cdot X_{1}=\left(\mu_{1 M} \cdot \frac{S_{1}}{K_{S 1}+S_{1}}\right) \cdot X_{1}$

$r_{1}$ : Rate of acidogenic reaction $(\mathrm{g} / \mathrm{L} \cdot \mathrm{d})$.

$\mu_{1}$ : Specific growth rate of acidogenic biomass $\left(\mathrm{d}^{-1}\right)$.

$\mu_{1 M}$ : Maximum specific growth rate of acidogenic biomass $\left(\mathrm{d}^{-1}\right)$.

$\mathrm{S}_{1}$ : Soluble organic matter concentration $(\mathrm{g} / \mathrm{L})$.

$K_{\mathrm{S} 1}$ : Affinity constant of acidogenic biomass (g/L).

$r_{2}=\mu_{2} \cdot X_{2}=\left(\mu_{2 M} \cdot \frac{S_{2}}{K_{s 2}+S_{2}+\frac{S_{2}^{2}}{K_{12}}}\right) \cdot X_{2}$

[Eq. 4]

$r_{2}$ : Rate of methanogenic reaction $(\mathrm{g} / \mathrm{L} \cdot \mathrm{d})$.

$\mu_{2}$ : Specific growth rate of methanogenic biomass $\left(\mathrm{d}^{-1}\right)$.

$\mathrm{X}_{2}$ : Methanogenic biomass concentration $(\mathrm{g} / \mathrm{L})$.

$\mu_{2 \mathrm{M}}$ : Maximum specific growth rate of methanogenic biomass $\left(d^{-1}\right)$.

$\mathrm{K}_{\mathrm{s} 2}$ : Affinity constant of methanogenic biomass (mmol/L).

$\mathrm{K}_{12}$ : Inhibition constant of methanogenic biomass $(\mathrm{mmol} / \mathrm{L})$.

$\mathrm{S}_{2}$ : Acetic acid concentration (mmol/L).

The system of equations was solved with Matlab ${ }^{\circledR}$ Software (Matrix Laboratory). From the uploaded input variables (tCOD, $s C O D$, VFAs and alkalinity), the model calculated the outputs, i.e. the effluent characteristics. The initial conditions considered were: an initial biomass concentration of $5 \mathrm{~g} \mathrm{VSS} / \mathrm{L}$, the methanogenic population accounting for $25 \%$ of the total, a $t$ COD of $0.5 \mathrm{~g} / \mathrm{L}$, with $0.35 \mathrm{~g} / \mathrm{L}$ and $0.15 \mathrm{~g} / \mathrm{L}$ particulate COD ( $p C O D$ ) and soluble COD (sCOD), respectively; and the VFA concentrations were assumed to be negligible.

\section{RESULTS AND DISCUSSION}

\section{ASBR operation}

Figure 3 shows the reactor performance during the 240 days of operation. The $t$ COD,sCOD and TSS levels in the influent varied between 300-600 mg/L, 100-200 mg/L and 200-400 mg/L, respectively. TSS content in the effluent was not affected by the OLR applied (around $100 \mathrm{mg} / \mathrm{L}$ ). However, the COD concentrations remained almost constant during the first two phases, around $150 \mathrm{mg}$ $t \mathrm{COD} / \mathrm{L}$ and $50 \mathrm{mg} s \mathrm{COD} / \mathrm{L}$, but increased to 300 and 200 $\mathrm{mg} / \mathrm{L}$, respectively, in the last phase. Organic matter removal efficiencies decreased from $50-60 \%$ (phases I and II) to $15-25 \%$ (phase III), which was probably due to the shorter phase III reaction time, which caused the reactor to work as a hydrolytic-acidogenic system. In contrast, the suspended solids removal efficiency increased slightly from $40-50 \%$ (phases I and II) to $60-70 \%$ (phase III).

The reactor $\mathrm{pH}$ remained constant during the experimental period with values around $7.19 \pm 0.11,7.26 \pm 0.18$ and 7.17 \pm 0.15 in phases I, II and III, respectively. As shown in Figure 3d, the alkalinity levels remained constant in phases I and II (around $600 \mathrm{mg} / \mathrm{L}$ of TA), indicating process stability. In phase III, even though the IA (related to VFA concentration) increased slightly, the total and partial alkalinity did not vary significantly, thus indicating that the process remained stable.

In phases I and II, VFA concentrations in the effluent were negligible (Figure 3e), which indicates that the reaction time allowed the methanogenesis to proceed. However, in phase III, only the hydrolysis and acidogenesis occurred because no methanogenic activity was detected. The specific methanogenic activity diminished from $0.69 \pm 0.01$ $\mathrm{gCOD}_{\mathrm{CH} 4} / \mathrm{gVSS} \times \mathrm{x}$ d in phase $\mathrm{I}$ to $0.55 \pm 0.01$ $\mathrm{gCOD}_{\mathrm{CH} 4} / \mathrm{gVSS} \mathrm{x} d \mathrm{~d}$ in phase $\mathrm{II}$, and disappeared completely in phase III. The main reason for the methanization blockage might be the shorter reaction time applied in phase III, because it is known that the methanogenic population grows slower than acidogenic bacteria. From Figure 4d, the acidogenic rate was noticeably greater than the methanogenic rate during the reaction time. During this latter phase, acetic acid was the main component of VFA, reaching concentrations of up to $200 \mathrm{mg} / \mathrm{L}$, which at this level are not expected to inhibit methanization.

Bodik et al. (2002) studied the performance of an ASBR treating domestic wastewater, obtaining an organic matter removal efficiency of $88 \%$. The reactor influent was raw domestic wastewater supplemented with glucose and 

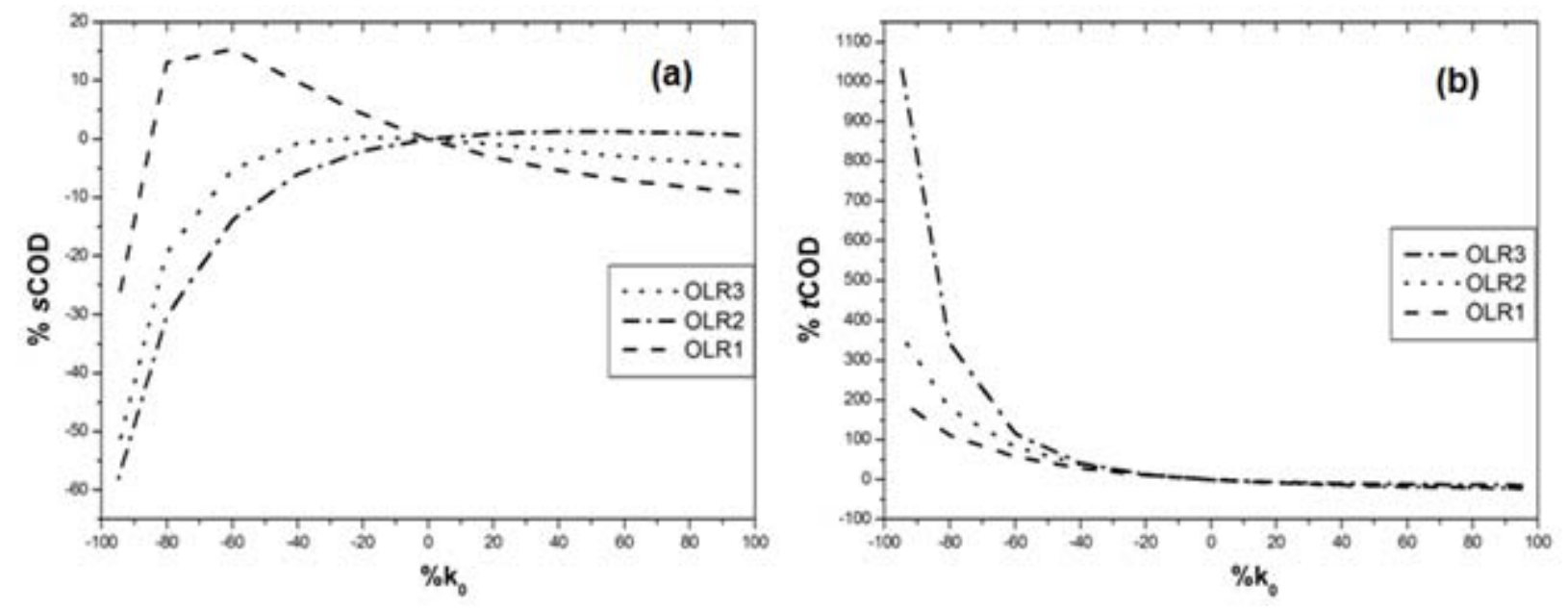

Figure 6. Variation (\%) of soluble (a) and total (b) COD concentrations at the end of the reaction time with $\mathrm{k}_{0}$ at the three OLRs studied. Results obtained during model validation were used as reference.

acetate, which comprised about $60 \%$ of the feeding COD, thus reaching a final total COD feed concentration of 650 $\mathrm{mg} / \mathrm{L}$. These treatment conditions were significantly more advantageous for anaerobic digestion. Alvarez et al. (2004) treated domestic wastewater (tCOD: 330 - $360 \mathrm{mg} / \mathrm{L}$ ) in an UASB reactor reaching total COD removal efficiencies of $60 \%$. Lew et al. (2004) reported COD removal efficiencies up to $75 \%$ in a two-phase system (UASB + anaerobic filter) operated at high OLR (around $5 \mathrm{~kg} \mathrm{COD} / \mathrm{m}^{3} \mathrm{x}$ d); however, solids accumulation in both reactors occurred. Ratusznei et al. (2001) treated synthetic domestic wastewater in an anaerobic sequencing batch biofilm reactor (ASBBR) with low total suspended solids (TSS) concentration, achieving total COD removal efficiencies of $85 \%$, but at a lower OLR (around $0.3 \mathrm{~kg} \mathrm{COD} / \mathrm{m}^{3} \cdot \mathrm{d}$ ) than those applied in this study (0.4-1.2 $\mathrm{kg} \mathrm{COD} / \mathrm{m}^{3} \mathrm{x}$ d). Sarti et al. (2007) studied two different mixing systems in a pilot ASBR treating domestic wastewater, at a similar OLR range to the range applied in this study. The reactor with liquid recirculation showed a lower $t$ COD removal efficiency (40\%) than that obtained in the present work, while the values obtained in the ASBR operated with mechanical mixing were similar (60\%).

Figure 4 shows the variation of sCOD concentration during the reaction stage of each phase of operation. In phase I (Figure 4a), sCOD concentrations decreased during the first $3 \mathrm{hrs}$, indicating a quick degradation of the soluble organic matter present in the influent. Afterwards, the sCOD increased due to the solubilization of the suspended organic matter during the hydrolysis step. Finally, the sCOD decreased and provided the VFA degradation. Similar behavior was found in phase II (Figure 4b), although methanogenesis did not occur completely. During these two phases, the VFA concentrations were close to the analytical method detection limit (data not shown).

However, a different profile was obtained for phase III (Figure 4c), where sCOD increased quickly within the first hour due to hydrolysis and remained constant for the rest of the reaction stage. Figure 4d shows the VFA level variation during the reaction stage of this last phase. The acetic acid levels increased continuously up to approximately 200 $\mathrm{mg} / \mathrm{L}$, whereas propionic and butyric acid concentrations remained constant with low values $(<40 \mathrm{mg} / \mathrm{L})$. Assuming negligible activity of the methanogenic population, the ASBR VFA productivity during this acidogenic-hydrolytic operation (phase III) can be determined. Two clear zones can be differentiated (Figure 4e). In the first zone (first 1 hr), the VFA productivity was almost 10 times higher than in the second zone, showing the fast acidification of the sCOD present in the influent. In the second zone (last 7 hrs), the hydrolysis of suspended organic matter likely limited the acidification process.

\section{Model evaluation}

Table 1 shows the kinetic parameters used for the model evaluation, which were selected from several studies carried out at operational conditions similar to the present work. All yield coefficients were taken from Bernard et al. (2001).

Figure 5 shows the comparison between the experimental and modeled data. During the first 30 days (phase I), the model predicted lower values of $t$ COD than the data obtained experimentally (Figure 5a). This result can be explained by the fact that the second assumption made related to biomass concentration at the beginning of each cycle was not met, since the biomass settleability was very poor during the first days of operation and a continuous washout occurred. At the beginning of phase III, the model also predicted a $t$ COD lower than the experimental values, which is related to the instability of the system after the increase in the OLR; in contrast, more stable experimental values were obtained at the end of this phase, which were closer to the modeled ones. 
Table 1. Kinetic parameters.

\begin{tabular}{|c|c|c|c|c|}
\hline Kinetic parameters & Unit & Value & Substrate & Reference \\
\hline$\mu_{1 \mathrm{~m}}$ & $\mathrm{~d}^{-1}$ & 1.20 & - & Bernard et al. (2001) \\
\hline$\mu_{2 \mathrm{~m}}$ & $\mathrm{~d}^{-1}$ & 0.74 & Glucose & Bernard et al. (2001) \\
\hline $\mathrm{K}_{12}$ & $\mathrm{mg} / \mathrm{L}$ & 300 & Winery wastewater & Batstone et al. (2004) \\
\hline $\mathrm{K}_{\mathrm{S} 1}$ & $\mathrm{mg} / \mathrm{L}$ & 500 & Manure/oil & Angelidaki et al. (1999) \\
\hline $\mathrm{K}_{\mathrm{S} 2}$ & $\mathrm{mg} / \mathrm{L}$ & 213.4 & Acetate & Vavilin et al. (1996) \\
\hline $\mathrm{k}_{0}$ & $\mathrm{~d}^{-1}$ & 0.99 & Primary sludge & Ristow et al. (2006) \\
\hline
\end{tabular}

A better correlation was obtained for the sCOD (Figure 5b), although some deviations were also seen during phase II and at the beginning of phase III. This was probably due to the presence of other soluble compounds not defined in the model, such as ethanol or lactic acid.

Despite the low acetic acid concentrations measured, an appropriate correlation between the experimental and modeled results was obtained. The higher experimental values obtained during phase III compared to the modeled ones might be explained by the fact that the model considers that all the VFAs are in the form of acetic acid, while small concentrations of propionic and butyric acid were also found experimentally. These results suggest that the acetic acid oxidation rates were somewhat underestimated by the model, which would partially explain the lower acetate concentrations.

Deviations between the modeled data and experimental results obtained in ASBR reactors have been encountered by other authors as well. Batstone et al. (2004) used the ADM1 model to determine and validate kinetic parameters treating two synthetic wastewaters, based on ethanol and acetate, respectively. The $\mathrm{pH}$ and biogas production values obtained during some consecutive cycles were used for the parameters fit, and a good correlation between the modeled and the experimental data was obtained for the first cycles of operation. However, the results became worse after 6 weeks of operation, due to the assumption that the biomass concentration remains constant which is more critical for highly concentrated effluents. Similar profiles were achieved by Bagley and Brodkorb (1999), who, after 10 cycles of operation using glucose as substrate, observed substantial deviations between the modeled and the experimental data.

\section{Sensitivity analysis}

A wide range of hydrolysis catalytic constant $\left(\mathrm{d}^{-1}\right)$ $\left(\mathrm{k}_{0}\right)$ values have been reported, from $0.005 \mathrm{~d}^{-1}$ (Christ et al. 2000) to $0.76 \mathrm{~d}^{-1}$ (Shimizu et al. 1993) using lipids as substrate or $0.99 \mathrm{~d}^{-1}$ (Ristow et al. 2006) using primary sludge. The latter was used in this study. On the other hand, the fraction of particulate organic matter determined in this study was 0.7 (70\%); however particulate organic matter may undergo variations due to seasonal factors or uncontrolled industrial effluent dumping.

Figure 6 and Figure 7 show the effect of the $k_{0}$ and particulate organic matter fraction $(\alpha)$, respectively, on the $s C O D$ (Figure 6a and Figure 7a) and tCOD (Figure 6b and Figure $7 \mathrm{~b}$ ) concentration variation at the end of the reaction time. As a reference, the results obtained during model validation were used.

Lower $\mathrm{k}_{0}$ values than those used during model validation had an important effect on the ASBR performance, mainly on the $t C O D$ concentrations. The significant decrease in the $s C O D$ level indicates the accumulation of $p C O D$ in the sludge blanket, and thus the reduction of the total activity of the anaerobic biomass. This effect was more noticeable at the highest OLR applied (OLR3). These results indicate that the underestimation of $\mathrm{k}_{0}$ could impair the model prediction severely. In contrast, an overestimation of the $\mathrm{k}_{0}$ values did not affect the model results.

In general, $\alpha$ slightly affected the process results (Figure 7). A small under or overestimation (up to $30 \%$ ) resulted in very low $s C O D$ and $t$ COD variations (up to $15 \%$ ). Higher variation of $\alpha$ value gave rise to a maximum variation of $s \mathrm{COD}$ and $t$ COD of 15 and 30\%, respectively. 

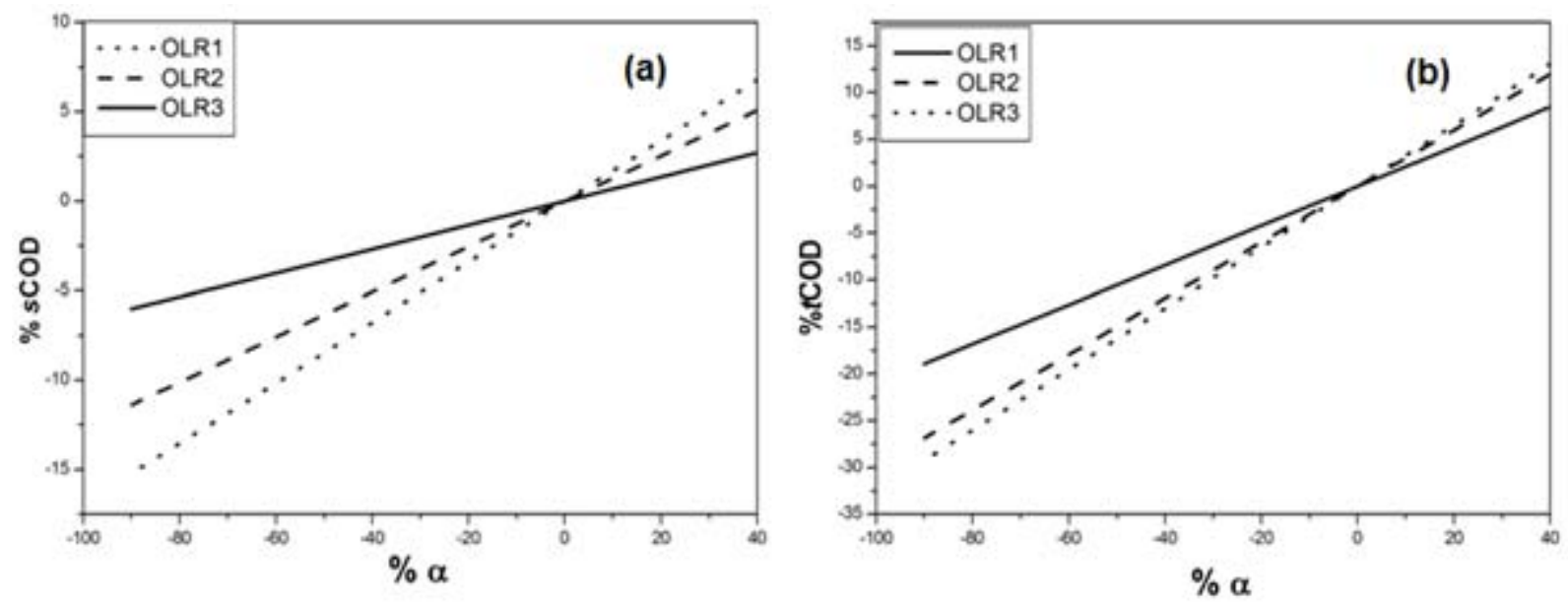

Figure 7. Variation (\%) of the soluble (a) and total (b) COD concentrations at the end of the reaction time with $\alpha$ at the three OLRs studied. Results obtained during model validation were used as reference.

\section{CONCLUDING REMARKS}

The anaerobic treatment of low strength sewage with high suspended organic matter content, in an ASBR reactor was successful up to an OLR of around $1 \mathrm{~kg} C O D / \mathrm{m}^{3} \mathrm{x} \mathrm{d}$ resulting in total COD removal efficiencies of $50-60 \%$. Higher OLR values $\left(1.2 \mathrm{~kg} \mathrm{COD} / \mathrm{m}^{3} \mathrm{x}\right.$ d) provoked the washout of the methanogenic biomass, thus causing the reactor to behave as a hydrolytic-acidogenic system.

A simplified model, considering two populations and three processes, was developed and implemented to predict ASBR performance. The resulting model predicted quite accurately the reactor behavior during the 8 month experimental period in terms of COD and acetic acid concentrations. Deviations were due to biomass washout, which was not considered in the model.

\section{REFERENCES}

ALVAREZ, J.A.; ARMSTRONG, E.; PRESAS, J.; GOMEZ, M. and SOTO, M. Performance of a UASBdigester system treating domestic wastewater. Environmental Technology, October 2004, vol. 25, no. 10, p. 1189-1199.

ANGELIDAKI, Irini; ELLEGAARD, Lars and AHRING, Birgitte K. A comprehensive model of anaerobic bioconversion of complex substrates to biogas. Biotechnology and Bioengineering, May 1999, vol. 63, no. 3, p. 363-372.

APHA, AWWA and WPCF. Standard method for the examination of water and wastewater. $19^{\text {th }}$ ed. Washington, D.C., American Public Health Association, 1995. 1325 p. ISBN 0-87553-235-7.

BAGLEY, David and BRODKORB, Toby S. Modeling microbial kinetics in an anaerobic sequencing batch reactor-model development and experimental validation. Water Environment Research, November-December 1999, vol. 71, no. 7, p. 1320-1332.

BATSTONE, D.J.; KELLER, J.; ANGELIDAKI, I.; KALYUZHNYI, S.V.; PAVLOSTATHIS, S.G.; ROZZI, A.; SANDERS, W.T.; SIEGRIST, H. and VAVILIN, V.A. Anaerobic digestion model no. 1. (ADM1). Water Science and Technology, 2002, vol. 45, no. 10, p. 65-73.

BATSTONE, D.J.; TORRIJOS, M.; RUIZ, C. and SCHMIDT, J.E. Use of an anaerobic sequencing batch reactor for parameter estimation in modelling of anaerobic digestion. Water Science and Technology, 2004, vol. 50, no. 10 , p. 295-303.

BERNARD, Olivier; HADJ-SADOK, Zakaria; DOCHAIN, Denis; GENOVESI, Antoine and STEYER, Jean-Philippe. Dynamical model development and parameter identification for an anaerobic wastewater treatment process. Biotechnology and Bioengineering, November 2001, vol. 75, no. 4, p. 424-438.

BODIK, Igor; HERDOVÁ, Bronislava and DRTIL, Miloslav. The use of upflow anaerobic filter and An SBR for wastewater treatment at ambient temperature. Water Research, February 2002, vol. 36, no. 4, p. 1084-1088.

CHRIST, O.; WILDERER, P.A.; ANGERHOFER, R. and FAULSTICH, M. Mathematical modeling of the hydrolysis of anaerobic processes. Water Science and Technology, 2000, vol. 41, no. 3, p. 61-65.

DOCHAIN, Denis and VANROLLEGHEM, Peter. Dynamical modelling and estimation in wastewater treatment processes. London, IWA Publishing, 2001. 342 p. ISBN 1-900222-50-7 
KESHTKAR, A.; GHAFORIAN, H.; ABOLHAMD, G. and MEYSSAMI, B. Dynamic simulation of cyclic batch anaerobic digestion of cattle manure. Bioresource Technology, October 2001, vol. 80, no. 1, p. 9-17.

LEW, B.; TARRE, S.; BELAVSKI, M. and GREEN, M. UASB reactor for domestic wastewater treatment at low temperatures: a comparison between a classical UASB and hybrid UASB-filter reactor. Water Science and Technology, 2004, vol. 49, no. 11-12, p. 295-301.

MASSÉ, D.I. and DROSTE, R.L. Comprehensive model of anaerobic digestion of swine manure slurry in a sequencing batch reactor. Water Research, October 2000, vol. 34, no. 12, p. 3087-3106.

MASSÉ, Daniel I.; MASSE, Lucie and CROTEAU, Francis. The effect of temperature fluctuations on psychrophilic anaerobic sequencing batch reactors treating swine manure. Bioresource Technology, February 2003, vol. 89, no. 1, p. 57-62.

MOCKAITIS, Gustavo; RATUSZNEI, Suzana M.; RODRIGUES, José Alberto D.; ZAIAT, Marcelo and FORESTI, Eugenio. Anaerobic whey treatment by a stirred sequencing batch reactor (ASBR): effects of organic loading and supplemented alkalinity. Journal of Environmental Management, April 2006, vol. 79, no. 2, p. 198-206.

NDEGWA, P.M.; HAMILTON, D.W.; LALMAN, J.A. and CUMBA, H.J. Effects of cycle-frequency and temperature on the performance of anaerobic sequencing batch reactors (ASBRs) treating swine waste. Bioresource Technology, April 2008, vol. 99, no. 6, p. 1972-1980.

RATUSZNEI, S.M.; RODRIGUES, J.A.D.; DE CAMARGO, E.F.M.; ZAIAT, M. and BORZANI, W. Influence of agitation rate on the performance of a stirred anaerobic sequencing batch reactor containing immobilized biomass. Water Science and Technology, 2001, vol. 44, no. 4, p. 305-312.

RISTOW, N.E.; SÖTEMANN, S.W.; WENTZEL, M.C.; LOEWENTHAL, R.E. and EKAMA, G.A. The effects of hydraulic retention time and feed COD concentration on the rate of hydrolysis of primary sewage sludge under methanogenic conditions. Water Science and Technology, 2006, vol. 54, no. 5, p. 91-100.

RODRIGUES, José Alberto; RATUSZNEI, Susana Maria; DE CAMARGO, Eduardo F.M. and ZAIAT, Marcelo. Influence of agitation rate on the performance of an anaerobic sequencing batch reactor containing granulated biomass treating low-strength wastewater. Advances in Environmental Research, January 2003, vol. 7, no. 2, p. 405-410.

RUIZ, C.; TORRIJOS, M.; SOUSBIE, P.; MARTINEZ, J.L. and MOLETTA, R. The anaerobic SBR process: basic principles for design and automation. Water Science and Technology, 2001, vol. 43, no. 3, p. 201-208.

RUIZ, C.; TORRIJOS, M.; SOUSBIE, P.; MARTINEZ, J.L.; MOLETTA, R. and DELGENES, J.P. Treatment of winery wastewater by an anaerobic sequencing batch reactor. Water Science and Technology, 2002, vol. 45, no. 10, p. 219-224.

SARTI, Arnaldo; FERNANDES, Bruna S.; ZAIAT, Marcelo and FORESTI, Eugenio. Anaerobic sequencing batch reactors in pilot-scale for domestic sewage treatment. Desalination, October 2007, vol. 216, no. 1-3, p. 174-182.

SHIMIZU, Tatsuo; KUDO, Kenzo and NASU, Yoshikazu. Anaerobic waste-activated sludge digestion-a bioconversion mechanism and kinetic model. Biotechnology and Bioengineering, 1993, vol. 41, no. 11, p. 1082-1091.

SUNG, Shihwu and DAGUE, Richard R. Laboratory studies on the anaerobic sequencing batch reactor. Water Environment Research, May-June 1995, vol. 67, no. 3, p. 294-301.

VAVILIN, V.A.; RYTOV, S.V. and LOKSHINA, L.Y. A description of hydrolysis kinetics in anaerobic degradation of particulate organic matter. Bioresource Technology, May-June 1996, vol. 56, no. 2-3, p. 229-237.

VAVILIN, V.A.; FERNANDEZ, B.; PALATSI, J. and FLOTATS, X. Hydrolysis kinetics in anaerobic degradation of particulate organic material: An overview. Waste Management, June 2008, vol. 28, no. 6, p. 939-951.

ZAIAT, M.; RODRIGUES, J.A.D.; RATUSZNEI, S.M.; DE CAMARGO, E.F. and BORZANI, W. Anaerobic sequencing batch reactors for wastewater treatment: a developing technology. Applied Microbiology and Biotechnology, January 2001, vol. 55, no. 1, p. 29-35. 